\title{
Communication
}

\author{
[Comunicação]
}

\section{Canine distemper virus and Toxoplasma gondii co-infection in dogs with neurological signs}

[Co-infecção pelo vírus da cinomose canina e Toxoplasma gondii em cães com sinais neurológicos]

\author{
D.M. Aguiar ${ }^{1}$, A.M. Amude ${ }^{2}$, L.G.F. Santos ${ }^{1}$, M.G. Ribeiro ${ }^{3}$, T.E.H. Ueno ${ }^{4}$, J. Megid ${ }^{3}$, \\ A.C. Paes $^{3}$, A.F. Alfieri ${ }^{5}$, A.A. Alfieri ${ }^{5}$, S.M. Gennari ${ }^{6}$ \\ ${ }^{1}$ Faculdade de Agronomia, Medicina Veterinária e Zootecnia - Universidade Federal de Mato Grosso - Cuiabá, MT \\ ${ }^{2}$ Faculdade de Medicina Veterinária - Universidade de Cuiabá - Cuiabá, MT \\ ${ }^{3}$ Faculdade de Medicina Veterinária e Zootecnia - Universidade Estadual Paulista, Botucatu, SP \\ ${ }^{4}$ Agência Paulista de Tecnologia dos Agronegócios - São José do Rio Preto, SP \\ ${ }^{5}$ Centro de Ciências Agrárias da Universidade Estadual de Londrina, PR \\ ${ }^{6}$ Faculdade de Medicina Veterinária e Zootecnia - Universidade de São Paulo - São Paulo, SP
}

Canine distemper virus (CDV) is a highly contagious virus that occurs worldwide and causes a fatal disease in carnivores. CDV is a member of the genus Morbillivirus belonging to the family Paramyxoviridae that are responsible to infect some cell line from epithelial tissues of respiratory, gastrointestinal or nervous systems (Greene, 2006). On early stage, CDV infection shows a great diversity of signs in dogs such as respiratory, gastrointestinal, and cutaneous. In sequence or weeks later, neurological injuries occurs and in some cases may be yet the only sign presented without any other previous or concomitant signs (Amude et al., 2007). In acute canine distemper encephalitis, CDV produces immunosuppression by acting directly on CD4+ cells. Therefore, dogs infected with CDV are more susceptible to develop secondary infections by Toxoplasma gondii and Neospora caninum, considered two neurotropic opportunists protozoan (Greene, 2006).

The aim of this study was to observe a possible association between CDV and $T$. gondii in dogs admitted at the Animal Infectious Diseases Service at the Universidade Estadual Paulista, Botucatu, SP, Brazil.

From 2001 to 2002, approximately 200 dogs suspected of CDV infection were attended in this
Service. From this total, 21 (12 males and nine females) dogs, with age ranging from 3 to 36 months, of different breeds and presenting classic signs of CDV were evaluated in this study.

Blood samples were obtained for detection of antibodies against $N$. caninum and $T$. gondii in serum according to Azevedo et al. (2005). Antibodies were detected by means of Indirect Fluorescence Antibody Test (IFAT) using tachyzoites of NC-1 strain of $N$. caninum propagated in VERO cell culture (IFAT $\geq 50$ ) and RH strain tachyzoites of $T$. gondii propagated in Swiss mice (IFAT $\geq 64$ ).

Even with instituted treatment (data not shown), all the selected animals died, and samples from central nervous system (CNS) were aseptically collected and evaluated by the presence of CDV RNA by RT-PCR assay. The RNA was extracted according to Boom et al. (1990). An aliquot of $300 \mu \mathrm{L}$ of suspension $(20 \% \mathrm{w} / \mathrm{v})$ of frozen fragments in phosphate-buffered saline (PBS pH 7.2) was evaluated. The RNA was eluated in diethylpyrocarbonate (DEPC)-treated water. The RT-PCR was carried out as previously described (Amude et al., 2006a), using the set of primers designed to amplify a 287bp amplicons from the CDV nucleoprotein (NP) gene (Frisk et al., 1999). Madin Darby canine kidney (MDCK)

Recebido em 2 de março de 2011

E-mail: danmoura@ufmt.br 
cells infected with CDV Rockborn strain were used as positive controls. RT-PCR was performed with negative controls of the RNA extraction (sterile ultrapure water) and the reaction (clinical sample from a dog with neurocryptococcosis). The identities of the RTPCR products were confirmed by restriction fragment length polymorphism (RFLP) with Hinf I (Invitrogen ${ }^{\circledR}$ Life Technology, USA) enzyme digestion.

The association between clinical signs, age, gender, breed, and RT-PCR for CDV and $T$. gondii and $N$. caninum serology results were evaluated using the Fisher's exact test, with confidence intervals of $95 \%$. Analyses were done using EpiInfo 6.04.

Overall, $17(80.9 \%)$ of the 21 fragments of the CNS examined presented CDV RNA by
RT-PCR assay. Concerning the clinical signs, only two dogs (\#18 and \#19) presented no neurological manifestations, however they were CDV positive by RT-PCR. From 19 dogs with neurological signs, 15 (79.0\%) were CDV RTPCR positive. The IFAT showed that eight $(38.1 \%)$ of the 21 examined dogs presented antibodies anti-T. gondii (IFAT $\geq 64$ ), and one $(4.7 \%)$ dog presented antibodies anti-N. caninum (IFAT $=100)$. Only one $(12.5 \%) \quad T$. gondii seropositive dog present no neurological signs (\#19 dog).

Table 1 shows the results of RT-PCR, IFAT, and clinical signs of each dog. No association $(\mathrm{P}>0.05)$ was detected between age, gender, breed, clinical signs, and infection by CDV, $T$. gondii, and $N$. caninum antibodies in dogs.

Table 1. Detection of canine distemper virus (CDV) by RT-PCR assay and antibodies anti-Toxoplasma gondii and anti-Neospora caninum by indirect fluorescent antibody test in dogs with neurological symptoms

\begin{tabular}{|c|c|c|c|c|c|c|}
\hline $\begin{array}{c}\text { Dog } \\
\text { Number }\end{array}$ & Gender & $\begin{array}{c}\text { Age } \\
\text { (months) }\end{array}$ & CDV & T. gondii & N. caninum & Clinical Symptom \\
\hline 1 & $\mathrm{~F}$ & 36 & + & - & - & myoclonus, weeping, and prostration \\
\hline 2 & $\mathrm{~F}$ & 36 & + & 4096 & - & myoclonus and paralysis of members \\
\hline 3 & M & 24 & + & 4096 & 100 & weeping, prostration, and hyperesthesia \\
\hline 4 & M & 4 & + & - & - & $\begin{array}{l}\text { myoclonus, weeping, convulsions, cough, } \\
\text { diarrhea, and ocular discharge }\end{array}$ \\
\hline 5 & $\mathrm{~F}$ & 7 & + & - & - & $\begin{array}{l}\text { myoclonus, weeping, prostration, cough, } \\
\text { and diarrhea }\end{array}$ \\
\hline 6 & M & 36 & + & - & - & cough, nasal discharge, and ataxia \\
\hline 7 & M & 13 & + & 128 & - & myoclonus, prostration, and convulsions \\
\hline 8 & M & $>36$ & + & - & - & myoclonus, weeping, and ataxia \\
\hline 9 & M & 12 & + & - & - & $\begin{array}{l}\text { myoclonus, convulsions, cough, diarrhea, } \\
\text { and ocular discharge }\end{array}$ \\
\hline 10 & M & 36 & - & - & - & paralysis of members and convulsion \\
\hline 11 & M & 4 & - & - & - & $\begin{array}{l}\text { myoclonus, paralysis of members, cough, } \\
\text { ocular and nasal discharges }\end{array}$ \\
\hline 12 & $\mathrm{~F}$ & 5 & - & - & - & myoclonus and convulsions \\
\hline 13 & $\mathrm{~F}$ & $>36$ & + & 8192 & - & ataxia, paddling, and walk in circles \\
\hline 14 & $\mathrm{~F}$ & $>36$ & - & 1024 & - & myoclonus and prostration \\
\hline 15 & $\mathrm{~F}$ & 18 & + & - & - & myoclonus and prostration \\
\hline 16 & $\mathrm{~F}$ & $>36$ & + & 1024 & - & $\begin{array}{l}\text { myoclonus, paralysis of members, ocular } \\
\text { and nasal discharges }\end{array}$ \\
\hline 17 & M & 4 & + & - & - & $\begin{array}{l}\text { myoclonus, prostration, hyperesthesia, and } \\
\text { ataxia } \\
\text { cough, diarrhea, ocular and nasal }\end{array}$ \\
\hline 18 & M & 16 & + & - & - & discharges \\
\hline 19 & M & 3 & + & 2048 & - & prostration and diarrhea \\
\hline 20 & M & $>36$ & + & - & - & hyperesthesia and convulsions \\
\hline 21 & $\mathrm{~F}$ & 24 & + & 2048 & - & myoclonus \\
\hline
\end{tabular}

$\mathrm{M}=$ Male; $\mathrm{F}=$ Female 
Distemper is yet recognized as an important cause of neurological disease in dogs, even in animals presented without the classical form of CDV infection (Amude et al., 2007). Although the widespread use of vaccination since the 1950s and 1960s markedly reduced worldwide the incidence of the disease, outbreaks still occur and neurological manifestations are considered important manifestations of distemper (Tipold et al., 1992). The results showed high rate $(79.0 \%)$ of CDV infection in dogs with neurological signs. In contrast, four dogs with neurologic manifestation were not positive to CDV indicating the importance of the differential diagnosis. One out of these four dogs had high antibodies titer against $T$. gondii $($ IFAT $=1024)$.

Furthermore, seven (41.1\%) dogs showed simultaneously positive RT-PCR for CDV RNA and high titers (IFAT $\geq 128$ ) of antibodies to $T$. gondii, characterizing co-infection. In contrast, only one $(4.7 \%)$ dog presented lower titer (IFAT $=100$ ) against $N$. caninum.

Of the 17 dogs with CDV, 15 (88.2\%) had classic and severe neurological manifestations. Others signs of CDV infection (Greene, 2006) such as prostration $(87.5 \%)$ and cough $(83.3 \%)$ were also recognized in those dogs. Among neurological symptoms, $14 \quad(73.6 \%)$ dogs presented myoclonus; this sign was considered the most frequent neurological sign of distemper, being $11(78.5 \%)$ determinated in CDV positive animals. Myoclonus has been considered highly suggestive of canine distemper, although other CDV-free neurological diseases reported in dogs can also be present with myoclonic-like movements (Amude et al., 2006b; Amude et al.,
2007). In addition, other paramyxoviruses infections and lead poisoning may also be presented with myoclonic movements (Amude et al., 2006b).

Eight dogs had positive serology to $T$. gondii, being seven $(87.5 \%)$ with neurological symptoms. Neurological deficits suggesting damages on nervous systems are one of some symptoms observed in $T$. gondii infections in dogs. The type and severity of clinical illness depend on the degree and localization of tissue injury, in which cell necrosis is caused by the intracellular growth of T. gondii (Greene, 2006). Silva et al. (2007) studying dogs that died due to nervous distemper, observed the presence of focal hemorrhagic and malacia in brain related to the presence of $T$. gondii cysts.

Despite a higher number of dogs suffering nervous disease showing positive RT-PCR results for CDV RNA and positive antibody titers simultaneously to $T$. gondii, these associations were not confirmed. However, the results of the present study reinforce that coinfection between these both neurovirulent infectious agents can increase the severity of neurological manifestations in dogs. On the other side $N$. caninum antibodies showed reduced association with dogs presenting neurological signs and CDV and T. gondii positive animals, indicative that neosporosis might play a low role in dogs with neurological manifestation in this region.

Keywords: dogs, canine distemper, toxoplasmosis, Neospora caninum, co-infection

\section{RESUMO}

O presente estudo relata a ocorrência de co-infecção entre o vírus da cinomose canina (CDV) $e$ Toxoplama gondii em cães com sinais neurológicos. Amostras de soro e tecido nervoso (pos-mortem) de 21 cães, suspeitos de cinomose canina foram analisadas pela Reação de Imunofluorecência indireta (RIFI) para pesquisa de anticorpos contra $\mathrm{T}$. gondii $e \mathrm{~N}$. caninum e por RT-PCR para CDV. Dezessete $(80,9 \%)$ cães foram positivos para o CDV pela RT-PCR e $8(38,1 \%)$ foram positivos para anticorpos contra T. gondii. Sete cães $(41,1 \%)$ apresentaram-se positivos para ambos agentes, caracterizando processo de co-infecção. Somente $1(4,7 \%)$ cão foi soropositivo para N. caninum (RIFI=100), entretanto este mesmo animal foi positivo para $\mathrm{T}$. gondii $(R I F I=4096)$ e para $C D V(R T-P C R)$.

Palavras-chave: cães, cinomose canina, toxoplasmose, Neospora caninum, co-infecção 


\section{ACKNOWLEDGMENTS}

We are grateful to Coordenação de Aperfeiçoamento de Pessoal de Nivel Superior for the grant to L.G.F. dos Santos and to Conselho Nacional de Desenvolvimento Científico e Tecnológico for the grant to M.G. Ribeiro, J. Megid, A.A. Alfieri, and S.M. Gennari.

\section{REFERENCES}

AMUDE, A.M.; ALFIERI, A.A.; ALFIERI, A.F. Antemortem diagnosis of CDV infection by RT PCR in distemper dogs with neurological deficits without the typical clinical presentation. Vet. Res. Commun., v.30, p.679-687, 2006 a.

AMUDE, A.M.; ALFIERI, A.A.; ALFIERI, A.F. The nervous form of distemper. Vet. Zootec., v.13, p.125-136, 2006b.

AMUDE, A.M.; ALFIERI, A.A.; ALFIERI, A.F. Clinicopathological findings in dogs with distemper encephalomyelitis presented without characteristic signs of the disease. Res. Vet. Sci., v.82, p.416-422, 2007.

AZEVEDO, S.S.; BATISTA, C.S.A.; VASCONCELLOS, S.A. et al. Seroepidemiology of Toxoplasma gondii and Neospora caninum in dogs from the state of Paraíba, Northeast region of Brazil. Res. Vet. Sci., v.79, p.51-56, 2005.
BOOM, R.; SOL, C.J.A., SALIMANS, M.M.M. et al. Rapid and simple method for purification of nucleic acids. J. Clin. Microbiol., v.28, p.495503, 1990.

FRISK, A.L.; KONIG, M.; MORITZ, A. et al. Detection of canine distemper virus nucleoprotein RNA by reverse transcription-PCR using serum, whole blood, and cerebrospinal fluid from dogs with distemper. J. Clin. Microbiol., v.37, p.3634-3643, 1999.

GREENE, C.E. (Ed). Infectious diseases of the dog and cat. 3.ed. Philadelphia: Saunders Elsevier Saunders Company. 2006. 1424 p.

SILVA, M.C.; FIGHERA, R.A.; BRUM, J.S. et al. Aspectos clinico-patológicos de 620 casos neurológicos de cinomose em cães. Pesq. Vet. Bras., v.27, p.215-220, 2007.

TIPOLD, A.; VANDEVELDE, M.; JAGGY, A. Neurological manifestations of canine distemper virus infection. J. Small An. Pract., v.33, p.466470, 1992. 